\title{
Ocular biometry and refractive changes post sutureless vitrectomy surgery
}

Raja Nor Farahiyah Raja Othman ${ }^{1,2}$, Zabri Kamaruddin², Selva Raja Vengadasalam², Mushawiahti Mustapha ${ }^{1}$

${ }^{1}$ Department Ophthalmology, Hospital Canselor Tuanku Muhriz, Kuala Lumpur, Malaysia; ${ }^{2}$ Department Ophthalmology, Hospital Selayang, Selangor, Malaysia

\section{Abstract}

Introduction: Pars plana vitrectomy (PPV) without endotamponade should not induce significant change to the refractive status of the eye. However, several studies have reported minor refractive changes after plain vitrectomy.

Purpose: To compare the changes in refraction following PPV and to examine the biometry parameters that may affect the refractive change.

Materials and methods: In this prospective cohort study, patients who were listed for 23-gauge 3-port PPV without buckling or silicone oil tamponade were enrolled between December 2015 and September 2017. Autorefraction, keratometry, anterior chamber depth (ACD), and axial length $(A L)$ were measured preoperatively and three months postoperatively.

Results: This study involved 41 eyes from 38 patients. The mean spherical equivalent (SE) before PPV was -1.08 dioptres (D), (standard deviation (SD) 2.18), which changed to a mean of $-1.88 \mathrm{D}$ (SD 2.20) postoperatively. The mean SE change was - $0.80 \mathrm{D}$ (SD $1.61,95 \%$ confidence interval $(\mathrm{Cl})-1.31$ to $0.30 \mathrm{D}, \mathrm{P}=0.003)$. The median astigmatism before PPV was $0.69 \mathrm{D}$ (Interquartile range (IQR) $0.69 \mathrm{D}$ ) reduced to $0.66 \mathrm{D}$ (IQR $0.60 \mathrm{D})$ after PPV $(\mathrm{P}=0.882)$. Median ACD preoperatively was $3.55 \mathrm{~mm}$ (IQR $0.76 \mathrm{~mm}$ ) and reduced postoperatively to $3.44 \mathrm{~mm}$ (IQR $0.67 \mathrm{~mm}),(P=0.028)$. The median AL was $23.36 \mathrm{~mm}$ (IQR $1.42 \mathrm{~mm}$ ) and $23.48 \mathrm{~mm}$ (IQR $1.56 \mathrm{~mm}$ ) before and after PPV, respectively, $(P=0.029)$. No significant $S E$ change was found between phakic and pseudophakic groups $(P=0.155)$.

Correspondence: Raja Nor Farahiyah Raja Othman, Dr.Oft (UKM), Department of Ophthalmology, Hospital Canselor Tuanku Muhriz, Jalan Yaacob Latif, Bandar Tun Razak, 56000 Batu 9 Cheras, Wilayah Persekutuan Kuala Lumpur, Malaysia.

E-mail: rajanorfarahiyah@gmail.com 
Conclusion: Patients experience myopic shift post plain PPV, possibly due to the reduction of ACD. The ACD tended to be shorter in the pseudophakic group, suggesting that the myopic shift in the phakic group may be a result of the development of nuclear sclerosis cataract.

Keywords: anterior chamber, biometry, refraction, vitrectomy

\section{Biometri okular dan perubahan refraktif selepas pembedahan vitrektomi tanpa jahitan}

\section{Abstrak}

Pengenalan: Vitrektomi pars plana (PPV) tanpa endotamponad tidak boleh menyebabkan perubahan ketara pada status refraktif mata. Walau bagaimanapun, beberapa kajian telah melaporkan perubahan refraktif kecil selepas vitrektomi biasa.

Tujuan: Untuk membandingkan perubahan dalam refraksi berikutan dari PPV dan untuk mengkaji parameter biometri yang boleh menjejaskan perubahan refraktif. Bahan dan kaedah: Dalam kajian kohort prospektif ini, pesakit yang disenaraikan untuk PPV 3-port 3-port tanpa troll atau minyak silikon tamponad telah direkrutkan antara Disember 2015 dan September 2017. Autorefraksi, keratometri, kedalaman ruang anterior $(\mathrm{ACD})$, dan paksi panjang $(\mathrm{AL})$ diukur secara pra pembedahan dan tiga bulan selepas pembedahan.

Keputusan: Kajian ini melibatkan 41 mata dari 38 pesakit. Median spherikal equivalent (SE) sebelum PPV adalah -1.08 dioptres (D), (sisihan piawai (SD) 2.18), yang berubah menjadi min -1.88 D (SD 2.20) selepas. Perubahan purata SE ialah $-0.80 \mathrm{D}$ (SD 1.61, 95\% selang keyakinan (CI) -1.31 hingga 0.30 D, P = 0.003). Adakah spherikal ekuivalen atau keseimbangan spherikal yang betul? Median Astigmatisma sebelum PPV adalah 0.69 D (Julian Interquartile (IQR) 0.69 D) dikurangkan kepada $0.66 \mathrm{D}$ (IQR 0.60 D) selepas PPV $(\mathrm{P}=0.882)$. Median ACD pra-operasi adalah 3.55 $\mathrm{mm}$ (IQR $0.76 \mathrm{~mm}$ ) dan berkurangan selepas operasi ke $3.44 \mathrm{~mm}$ (IQR $0.67 \mathrm{~mm}),(\mathrm{P}$ $=0.028$ ). Median AL adalah $23.36 \mathrm{~mm}$ (IQR $1.42 \mathrm{~mm}$ ) dan $23.48 \mathrm{~mm}$ (IQR $1.56 \mathrm{~mm}$ ) sebelum dan selepas PPV, $(\mathrm{P}=0.029)$. Tiada perubahan $\mathrm{SE}$ yang penting didapati di antara kumpulan fakik dan psuedofakik $(\mathrm{P}=0.155)$.

Kesimpulan: Pesakit mengalami enjakan myopik pasca PPV biasa, mungkin disebabkan pengurangan ACD. ACD cenderung lebih pendek dalam kumpulan pseudofakik, yang menunjukkan bahawa enjakan miopik dalam kumpulan fakik mungkin disebabkan oleh perkembangan katarak sklerosis nuklear. 
Kata kunci: ruang anterior, biometri, pembiasan, vitrektomi

\section{Introduction}

Pars plana vitrectomy (PPV) and scleral buckle surgery are routinely performed for various vitreoretinal pathologies. With advancement of technology, anatomical success rate has improved..$^{1-3}$ Scleral buckle surgery and PPV using silicone oil endotamponade are known to cause refractive changes. ${ }^{2,4,5}$ Scleral buckle increases axial length (AL) causing a myopic shift post-surgery. ${ }^{2,4,5}$

Theoretically, PPV alone without endotamponade should not induce significant refractive changes to the eye. However, several studies have reported refractive changes between $-0.26 \mathrm{D}$ and $-1.21 \mathrm{D}$ after plain primary PPV without buckling or silicone oil tamponade. ${ }^{6-10}$ Byrne et al. reported significant spherical equivalent (SE) changes after 20-gauge PPV in pseudophakic eyes for various diseases. ${ }^{7}$ A study in Taiwan described significant changes in refractive status after primary PPV in both phakic and pseudophakic eyes. ${ }^{8}$ However, the study was not able to describe the reason for such changes.

There are few studies that report potential reasons for this myopic shift. It could either be due to a reduction of anterior chamber depth (ACD)10-12 or an increase in $\mathrm{AL}^{3}$ To the best of our knowledge, this is the first prospective study directly looking at the possible association between refractive changes and various ocular biometry variables.

\section{Materials and methods}

\section{Ethics statement}

The protocol of this study was approved by the ethics committee of the National Medical Research Registry (NMRR-15-1146-25564 (IIR)) and the Hospital Canselor Tuanku Muhriz, and conformed to the Declaration of Helsinki. Written informed consent was obtained.

\section{Sampling strategy and recruitments}

A prospective cohort study was conducted from $1^{\text {st }}$ of December 2015 until $30^{\text {th }}$ of September 2017 involving patients referred to a tertiary eye care center in central Malaysia for various vitreoretinal conditions. Patients listed for vitrectomy were recruited.

\section{Inclusion and exclusion criteria}

In pre-existing pseudophakic eyes, an interoperative period greater than six months between cataract operation and PPV was allowed for refractive stabiliza- 
tion. Exclusion criteria for the study were patients with concurrent ocular pathology such as glaucoma or corneal disorders, previous ocular surgery, combined buckle surgery, and patients who required silicone oil endotamponade.

\section{Clinical method}

The required data was taken a day prior to surgery and three months after the operation. Refraction data was obtained with an autorefractometer (Nidek Autorefractometer, Model AR 600A, Nidek, Japan) and converted to SE. Non-contact optical biometry (IOL Master 500, Carl Zeiss Meditec AG, Germany) was used to study keratometry, $A C D$, and $A L$ of the globe. The corneal astigmatism was determined by differences in keratometry $(\mathrm{dK})$ along the flattest and the steepest meridian. Calibration of the instrument was done by the optometrist every week for the IOL Master and monthly for the Nidek Autorefractometer.

Vitrectomy was performed under local anaesthesia (retrobulbar and/or peribulbar) by two vitreoretinal surgeons of at least three years' experience. The surgical procedure was done using the standard 23-gauge vitrectomy system. Postoperatively, all patients received routine topical medications: guttae dexamethasone $0.1 \%$ and guttae chloramphenicol $0.5 \%$ every two hours. Patients were followed up at three months postoperatively and similar measurements were repeated.

\section{Sample size and methods}

The sampling method was purposive sampling, also known as selective sampling. It was homogeneous in nature. The sample size used was based on the formula Sample Size for Comparing Means formula, introduced by Wang et al. ${ }^{13}$ The formula was used to achieve $80 \%$ of power with reference to a similar study by Tseng et al. ${ }^{8}$ (38 eyes plus $20 \%$ dropout).

\section{Statistical analysis}

Statistical analysis was performed using Statistical Package for Social Science, version 24.0 (IBM, Armonk, USA) for Windows. Refractive status and biometry components (keratometry, $A C D$, and $A L$ ) were analyzed by paired t-test/independent t-test for normally distributed data and Wilcoxon-Mann-Whitney test for non-normally distributed data, respectively. A P-value $<0.05$ was considered statistically significant.

\section{Results}

Eighty-eight eyes were eligible for the study. Five cases were rescheduled or cancelled for various non-ocular reasons. Fourteen eyes had intraoperative silicone oil tamponade and another 28 patients were lost at follow up. Finally, a total of 41 


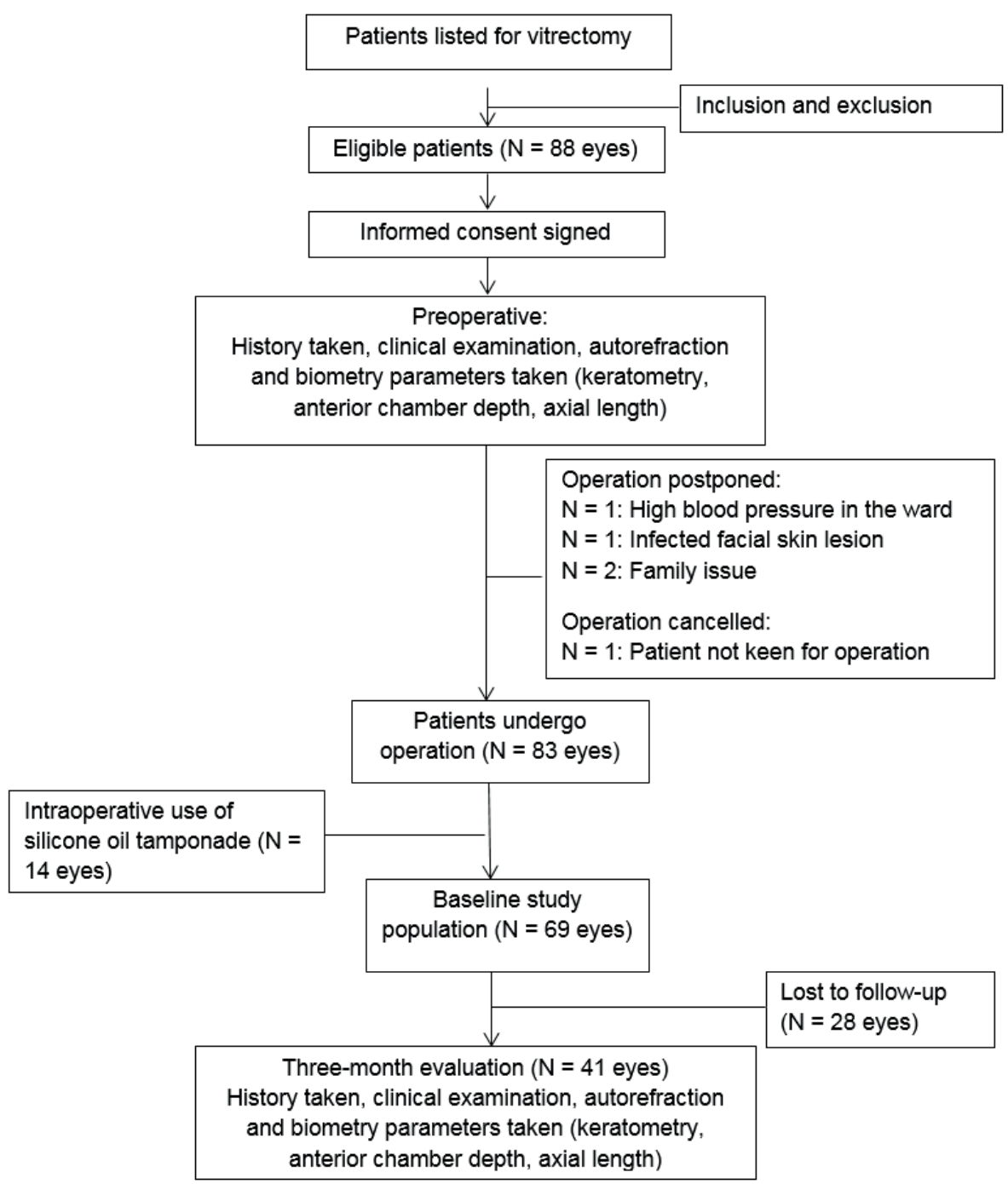

Fig. 1. Flow chart of the study 
eyes from 38 patients were recruited for the study (Fig. 1).

Mean age was 53.21 (Standard deviation [SD] 13.84) years, ranging from 22 to 76 years old. The majority were more than 40 years of age $(78.9 \%)$ (Table 1 ). There were 32 phakic (78\%) and 9 pseudophakic (22\%) eyes. Indications for vitrectomy were advanced diabetic eye disease (56.1\%), epiretinal membrane (17.1\%), vitreous haemorrhage (12.2\%), macular hole (9.8\%), and rhegmatogenous retinal detachment (4.9\%). Gas tamponade (air, sulfur hexafluoride, and perfluoropropane) was used in 37 eyes (90.2\%). Preoperative intraocular pressure (IOP) ranged from 6 to $20 \mathrm{mmHg}$, while the postoperative IOP ranged from 10 to $22 \mathrm{mmHg}$.

\section{Refractive changes}

Mean SE prior to vitrectomy was $-1.08 \pm 2.18$ D. Postoperatively, mean SE was $-1.88 \pm$ 2.20 D ( $\mathrm{P}=0.003)$. Myopic shift was more significant for the phakic group compared to the pseudophakic patients. (Table 2). Refractive changes were significant for SE $(P=0.002)$ but not for astigmatism $(P=0.722)$ in the phakic group. Whereas in pseudophakic eyes, both SE $(P=0.808)$ and astigmatism changes $(P=0.624)$ were not significant. SE changes between age group, gender, disease category, and with the use of gas tamponade were not significant.

\section{Ocular biometry changes}

ACD reduced significantly $(P=0.028)$ after surgery. There was no significant correlation between SE and the measured ocular parameters. Therefore, no further multivariate analysis was done.

\section{Discussion}

In our study, PPV without scleral buckle/silicone oil endotamponade resulted in an overall myopic shift of $-0.80 \mathrm{D}$. Tseng et al. described similar changes in their study. ${ }^{8}$ They concluded that myopic changes were possibly due to changes in the position of the macula/fovea postoperatively. Preoperative thickening due to macular oedema or traction may induce hyperopia. Postoperatively, surgical correction improved the anatomical configuration of the fovea. Hence, the surgical correction resulted in a myopic shift. However, the study was done retrospectively and lacked biometry information to support their findings. ${ }^{8}$ We found that myopic shift was more prominent in phakic compared to pseudophakic eyes. This could be due to changes of refractive compound within the crystalline lens or progression of cataract post-surgery. Although Byrne et al. reported similar myopic changes among pseudophakic eyes, ${ }^{7}$ we did not find the myopic shift value to be significant among our pseudophakic subjects. This could be due to the small number of pseudophakic eyes in our series. 
Table 1. Demographic data

\begin{tabular}{|l|l|}
\hline Demographic & N (\%) \\
\hline Age & Mean 53.21 (SD 13.84) \\
\hline$<40$ & $8(21.1)$ \\
\hline$>40$ & $30(78.9)$ \\
\hline Gender & \\
\hline Male & $24(63.2)$ \\
\hline Female & $14(36.8)$ \\
\hline Ethnicity & \\
\hline Malay & $18(47.4)$ \\
\hline Chinese & $11(28.9)$ \\
\hline Indian & $9(23.7)$ \\
\hline Laterality & \\
\hline Right & $15(36.6)$ \\
\hline Left & $26(63.4)$ \\
\hline Indication for PPV & \\
\hline Epiretinal membrane (ERM) & $7(17.1)$ \\
\hline Macula hole (MH) & $4(9.8)$ \\
\hline Mild vitreous haemorrhage & $5(12.2)$ \\
\hline Rhegmatogenous retinal detachment (RRD) & $2(4.9)$ \\
\hline Advanced diabetic eye disease (ADED) & $23(56.1)$ \\
\hline Lens status & \\
\hline Phakic & $32(78.0)$ \\
\hline Pseudophakic & $9(22.0)$ \\
\hline Tamponade agents used & \\
\hline No tamponade & $4(9.8)$ \\
\hline Gas & $37(90.2)$ \\
\hline Air & $23(56.1)$ \\
\hline Sulphur hexafluoride (SF6) & $2(14.3)$ \\
\hline Perfluoropropane (C3F8) & $12(85.7)$ \\
\hline
\end{tabular}

PPV: pars plana vitrectomy; N: number of participants; SD: standard deviation 
Table 2. Refractive changes before and after vitrectomy

\begin{tabular}{|c|c|c|c|c|}
\hline Biometry parameters & Groups (N) & $\begin{array}{l}\text { Before PPV } \\
\text { Mean (SD) } \\
\end{array}$ & $\begin{array}{l}\text { After PPV } \\
\text { Mean (SD) }\end{array}$ & P-value \\
\hline \multirow[t]{3}{*}{ SE\# } & Phakic (32) & $-1.09(2.40)$ & $-2.08(2.41)$ & 0.002 \\
\hline & Pseudophakic (9) & $-1.04(1.17)$ & $-1.16(0.95)$ & 0.808 \\
\hline & Overall (41) & $-1.08(2.18)$ & $-1.88(2.20)$ & 0.003 \\
\hline \multirow[t]{3}{*}{$\mathrm{dK}^{\star}$ (astigmatism) } & Phakic (32) & $0.61(0.84)$ & $0.63(0.67)$ & 0.722 \\
\hline & Pseudophakic (9) & $0.71(0.33)$ & $0.77(0.26)$ & 0.624 \\
\hline & Overall (41) & $0.69(0.69)$ & $0.66(0.60)$ & 0.882 \\
\hline \multirow[t]{3}{*}{$\mathrm{ACD}^{*}$} & Phakic (32) & $3.39(0.56)$ & $3.34(0.68)$ & 0.216 \\
\hline & Pseudophakic (9) & $4.86(1.09)$ & $3.94(0.92)$ & 0.043 \\
\hline & Overall (41) & $3.55(0.76)$ & $3.44(0.67)$ & 0.028 \\
\hline \multirow[t]{3}{*}{$A L^{*}$} & Phakic, (32) & $23.50(2.06)$ & $23.59(1.95)$ & 0.058 \\
\hline & Pseudophakic, (9) & $22.98(1.33)$ & $23.38(1.08)$ & 0.183 \\
\hline & Overall, (41) & $23.36(1.42)$ & $23.48(1.56)$ & 0.029 \\
\hline
\end{tabular}

$\mathrm{N}$ : number of eyes; PPV: pars plana vitrectomy; SD: standard deviation; SE: spherical equivalent (diopters); dK: difference of keratometry, K2 - K1 (astigmatism; diopters); ACD: anterior chamber depth (mm); AL: axial length ( $\mathrm{mm})$; " paired t-test; ${ }^{*}$ Wilcoxon signed rank test (Median (IQR)). 


\section{Anterior chamber depth}

We reported a significant reduction of ACD post vitrectomy. Similar findings were described by Seo et al. ${ }^{11}$ The study postulated reduction of zonule-vitreous adherence after surgery causing loosening of the zonules. This potentially resulted in anterior displacement of the lens-zonule diaphragm. ${ }^{11}$ Suzuki et al. also described the possibility of more severe capsular contraction in post-vitrectomized eyes, which might result in the anterior shifting phenomena. ${ }^{19}$ These postulations support our findings of prominent shallowing of ACD among pseudophakic eyes. ACD changes in phakic eyes were not significant; this could be due to better preservation of the peripheral vitreous around the zonules. Hence, less changes occur among these subjects.

Calik et al. studied the anterior segment parameters using a Pentacam Scheimpflug camera. The group reported reduction of ACD was related to the occurrence of supraciliary effusion early post-surgery.20 Unfortunately, their observation was only up to one month. Surgery potentially resulted in destruction of the blood-aqueous barrier, causing anatomical changes around the ciliary body. This could be another reason for the decreases in ACD and anterior chamber angular width. $^{21}$

\section{Axial length}

Our study showed significant changes in overall AL. Brazitikos et al. found a small increment in the $\mathrm{AL}(0.1 \mathrm{~mm})$ after vitrectomy. ${ }^{3}$ Their reasoning for this result was scleral stretching and thinning after surgery. ${ }^{22}$ However, other studies did not find significant changes in AL post retinal surgery. ${ }^{10,11}$ Leydolt et al. reported IOP of $24 \mathrm{mmHg}$ may cause a significant increment in AL of $0.023 \mathrm{~mm} .{ }^{23}$ The highest IOP in our study was documented as $20 \mathrm{mmHg}$ preoperatively and $22 \mathrm{mmHg}$ postoperatively. Therefore, it was unlikely for the IOP to contribute to the AL changes in our group of patients.

\section{Astigmatism}

Among our samples, astigmatism remained the same before and after surgery. This is consistent with previous studies, which described the presence of transient astigmatism. Measurement returned to baseline value at one to four months post-vitrectomy. ${ }^{14-16}$ Vitrectomy induced a significant steepening in relation to sutured trocar entry ports. ${ }^{15}$ After three months, the changes in scleral elasticity or loosening of the sutures allowed the cornea to flatten in the same meridian, ${ }^{14}$ contributing to nonsignificant changes in astigmatism. Even with the usage of a 20 -gauge cannula system, corneal topographic changes decreased at 3 months after surgery. ${ }^{14}$

\section{Myopic shift}

Our study suggests reduced $A C D$ and increased $A L$ contribute to the overall myopic 
changes in our cases. However, reduction of ACD was insignificant among phakic eyes. These findings suggest myopic shifts in phakic eyes were not due to the changes in ocular biometry, but more likely due to the development of nuclear sclerosis cataract, which is very common post-surgery. Okamoto and colleagues reported myopic progression three months after vitrectomy was due to the development of nuclear sclerosis cataract. ${ }^{24}$ At the same time, the development of cataract in post-vitrectomized eyes was significantly related to the patients' age. ${ }^{24}$

Further subgroup analysis of our small number of pseudophakic patients showed less significant changes in myopic shift despite decreasing ACD. Although the number of eyes was small, it may still suggest that the effect of anterior shifting of the lens-zonule diaphragm is negligible in pseudophakic patients.

\section{Limitations of the study and study benefits}

Limitations of our study were mainly due to the small number of pseudophakic eyes and lack of cataract progression monitoring. We did not look at changes of the crystalline lens as that was not part of the ocular biometry. Despite this limitation, we were able to provide important information on the biometric changes for small gauge vitrectomy surgery. To the best of our knowledge, this is the first study on refractive changes following 23-gauge PPV surgery among the Malaysian population.

\section{Conclusion}

In conclusion, there were significant myopic shifts in patients undergoing sutureless vitrectomy surgery among phakic eyes. Ocular biometry was more stable for phakic eyes compared to pseudophakic patients. The myopic shifts in phakic eyes were likely due to the refractive changes of the crystalline lens itself rather than the changes in biometry. Interestingly, despite shallower ACD post-surgery among pseudophakic eyes, myopic shift was not apparent.

\section{Recommendation}

Longer follow-up and larger number of pseudophakic eyes to be studied.

\section{Acknowledgements}

I would like to acknowledge the contribution made by Professor Dr. Mae-Lynn Catherine Bastion from Universiti Kebangsaan Malaysia and Associate Professor 


\section{Dr. Nilo Vincent DG. Flor Cruz from the Philippines who examined and edited the manuscript.}

\section{References}

1. Sun Q, Sun T, Xu Y, et al. Primary vitrectomy versus scleral buckling for the treatment of rhegmatogenous retinal detachment: a meta-analysis of randomized controlled clinical trials. Curr Eye Res. 2012;37(6):492-499

2. Sharma YR, Karunanithi S, Azad RV, et al. Functional and anatomic outcome of scleral buckling versus primary vitrectomy in pseudophakic retinal detachment. Acta Ophthalmol Scand. 2005;83(3):293297.

3. Brazitikos PD, Androudi S, Christen WG, et al. Primary pars versus scleral buckle surgery for the treatment of pseudophakic retinal detachment: a randomized clinical trial. Retina. 2005;25(8):957-964.

4. Stangos AN, Petropoulos IK, Brozou CG, et al. Pars-alone vs vitrectomy with scleral buckling for primary rhegmatogenous pseudophakic retinal detachment. Am J Ophthalmol. 2004;138(6):952958.

5. Habibabadi HF, Hashemi H, Jalali KH, et al. Refractive outcome of silicone oil removal and intraocular lens implantation using laser interferometry. Retina. 2005;25(2):162-166.

6. Shioya $\mathrm{M}$, Ogino $\mathrm{N}$, Shinjo $\mathrm{U}$. Change in postoperative refractive error when vitrectomy is added to intraocular lens implantation. J Cataract Refract Surg. 1997;23(8):1217-1220.

7. Byrne S, Ng J, Hildreth A, et al. Refractive change following pseudophakic vitrectomy. BMC Ophthalmol. 2008;8(1):19.

8. Tseng P-C, Woung L-C, Tseng G-L, et al. Refractive change after pars. Taiwan J Ophthalmol. 2012;2(1):18-21.

9. Hamoudi H, Kofod M, La Cour M. Refractive change after vitrectomy for epiretinal membrane in pseudophakic eyes. Acta Ophthalmol. 2013;91(5):434-436.

10. Huang C, Zhang T, Liu J, Tan R, Ji Q. Changes in axial length and anterior chamber depth after rhegmatogenous retinal detachment repair. J Clin Exp Ophthalmol. 2014;5(6):377.

11. Seo S, Seong MC, Lim HW, et al. The changes of anterior chamber depth, axial length, refractive errors after combined vitrectomy. J Korean Ophthalmol Soc. 2013;54(7):1032-1037.

12. Ünsal E, Eltutar K. Evaluation of the changes in anterior segment morphology with ultrasound biomicroscopy after vitrectomy without use of tamponade in pseudophakic eyes. Open J Ophthalmol. 2016;6(4):210-220.

13. Wang H, Chow SC. Sample size calculation for comparing means. In: D’Agostino RB, Sullivan L, Massaro J, ed. Wiley Encyclopedia of Clinical Trials. Hoboken, NJ: John Wiley and Sons, Inc; 2007.

14. Weinberger D, Lichter H, Loya N, et al. Corneal topographic changes after retinal and vitreous surgery. Ophthalmology. 1999;106(8):1521-1524.

15. Wirbelauer $\mathrm{C}$, Hoerauf $\mathrm{H}$, Roider J, et al. Corneal shape changes after pars. Graefes Arch Clin Exp Ophthalmol. 1998;236(11):822-828.

16. Mohamed AA, Abdrabbo M. Corneal topographic changes following trans-conjunctival 20 gauge sutureless vitrectomy (TC20V). Clin Ophthalmol. 2012;6:565-569. 
17. Bullimore MA, Fusaro RE, Adams CW. The repeatability of automated and clinician refraction. Optom Vis Sci. 1998;75(8):617-622.

18. Allen PM, Radhakrishnan H, O'Leary DJ. Repeatability and validity of the power refractor and the Nidek AR600-A in an adult population with healthy eyes. Optom Vis Sci. 2003;80(3):245-251.

19. Suzuki Y, Sakuraba T, Mizutani H, Matsuhashi H, Nakazawa M. Postoperative refractive error after simultaneous vitrectomy and cataract surgery. Ophthalmic Surgery, Lasers and Imaging Retina. 2000;31(4):271-5.

20. Çalık B, Öztürk M, Serdaroğulları H, et al. Evaluation of anterior segment parameters using pentacam in silicone oil-injected patients after pars. Indian J Ophthalmol. 2013;61(11):621-625.

21. Park SP, Ahn JK, Lee GH. Morphologic changes in the anterior segment after phacovitrectomy for proliferative diabetic retinopathy. J Cataract Refract Surg. 2009;35(5):868-873.

22. Jeoung JW, Chung H, Yu HG. Factors influencing refractive outcomes after combined phacoemulsification and pars: results of a prospective study. J Cataract Refrac Surg. 2007;33(1):108-114.

23. Leydolt C, Findl O, Drexler W. Effects of change in intraocular pressure on axial eye length and lens position. Eye (Lond.). 2008;22(5):657-661.

24. Okamoto Y, Okamoto F, Hiraoka T, et al. Refractive changes after lens-sparing vitrectomy for rhegmatogenous retinal detachment. Am J Ophthalmol. 2014;158(3):544-549. 